\title{
Sistem Pakar Untuk Diagnosa Hama dan Penyakit Pada Bunga Krisan Menggunakan Forward Chaining
}

\author{
Hanip Afandi ${ }^{1}$, Danang Arbian Sulistyo ${ }^{2}$ \\ STMIK Asia Malang \\ 1'hanipafandi@gmail.com, 2danang.arbian@ asia.ac.id
}

\begin{abstract}
ABSTRAK.Bunga krisan adalah jenis tumbuhan berbunga yang sering ditanam sebagai tanaman hias atau bunga petik. Petani bunga krisan rata-rata mempunyai pengetahuan yang kurang mengenai hama dan penyakit pada bunga krisan yang susah untuk diidentifikasi, sehingga terlambat dalam melakukan penanganan dan pecegahan yang nantinya akan berakibat pada menurunnya hasil panen bunga krisan. Sistem pakar dapat mengatasi permasalahan ini yaitu dengan merancang sebuah sistem komputer berbasis web yang terintegrasi dengan database dan bahasa pemrograman seperti PHP-MySQL sehingga dapat membantu petani bunga krisan di Poncokusumo untuk mendiagnosa hama dan penyakit tersebut.

Aplikasi sistem pakar dalam pengambilan keputusannya menggunakan mesin inferensi seperti Forward Chaining yang bekerja dengan menelusuri kasus-kasus berdasarkan rule-rule pada pohon keputusan. Diagnosa hama dan penyakit mengunakan metode forward chaining. Pada penelitian ini jenis penyakit yang dapat didiagnosa sebanyak 12 penyakit. Hasil dari implementasi sistem yaitu sistem akan memberikan pertanyaan berupa gejala-gejala yang dijawab oleh petani berdasarkan gejala yang dialami bunga krisan dan hasil dari proses tersebut sistem akan memberikan informasi hama atau penyakit apa yang dialaminya untuk mendapatkan solusi pengobatan dan pencegahannya. Pengujian yang digunakan yaitu pengujian akurasi dengan data uji sebanyak 21 pengujian.
\end{abstract}

Kata Kunci: Sistem Pakar,Bunga Krisan, Forward Chaining

\begin{abstract}
Chrysanthemum flowers are a type of flowering plant that is often planted as an ornamental plant or cut flower. Chrysanthemum flower farmers on average have less knowledge about pests and diseases in chrysanthemum flowers that are difficult to identify, so that it is too late in handling and prevention which will result in a decrease in the yield of chrysanthemum flowers. Expert system can solve this problem by designing a web-based computer system integrated with database and programming languages such as PHP-MySQL so as to help chrysanthemum farmers in Poncokusumo to diagnose pests and diseases. Expert system applications in decision making using inference engines such as Forward Chaining that works by tracing cases based on rules on the decision tree.

Diagnosis of Pests and Diseases using Forward Chaining method. In this study the types of diseases that can be diagnosed as many as 12 diseases. The results of the system implementation of the system gives questions in the form of symptoms that must be answered by the farmerbased on symptoms experienced by chrysanthemum flowers and the results of the process the system will provide information on what pests or diseases to get treatment solutions and prevention.Tests used are accuracy testing with 21 data tester.
\end{abstract}

Keywords: Expert System, Symptoms, chrysanthemum flower, Forward Chaining.

\section{PENDAHULUAN}

Krisan (Deandratheum grandiflora Tzvelev Syn. Chrysantemum Morifilium Ramat) merupakan tanaman hias bunga yang memiliki nilai ekonomi dengan prospektif yang dikembangkan secara komersial. Krisan merupakan salah satu komoditas tanaman hias penting di Jawa Timur. Pada tahun 2013 luas areal pertanaman krisan di Jawa Timur mencapai 3.419.192 m2 dengan produksi bunga potong 65.675.925 tangkai per tahun atau sekitar 17,00\% dari total produksi nasional (BPS 2013). Sentra produksi terdapat di Kecamatan Tutur Pasuruan, kecamatan Poncokusumo (Kabupaten Malang), Kota Batu dan mulai berkembang di kecamatan Pacet (Kabupaten Mojokerto), permasalahan yang timbul adalah banyak kerugian yang diakibatkan karena adanya penyakit tanaman bunga krisan yang terlambat untuk didiagnosis dan sudah mencapai tahap yang parah sehingga menyebabkan terjadinya gagal panen.

Dalam perkembangannya, penyakit dan hama yang menyerang umumnya menunjukkan sudah menunjukkan gejala awal yang terjadi, akan tetapi dikarenakan oleh ketidaktahuan para petani maka gejala dari hama dan penyakit tersebut akhirnya meluas dan akhirnya sulit untuk dikendalikan sehingga memperparah penyakit dan hama yang menyerang. Untuk saat ini pengetahuan mengenai gejala gejala tersebut hanya dimiliki oleh para ahli pertanian terkait, sedangkan para petani terkendala oleh watu dan kurangnya pengetahuan tentang penyakit dan hama dari bunga Krisan. Oleh karena itu, diharapkan aplikasi sistem pakar ini bisa menjembatani dan memberikan informasi yang akurat mengenai hama dan penyakit dari Bunga Krisan kepada para petani, khususnya para petani di Poncokusumo sekaligus dapat memberikan solusi penanggulangan sehingga resiko kerusakan tanaman dapat dikurangi secara signifikan. Oleh karena itu maka akan di rancang sebuah Sistem Pakar Untuk Mendiagnosa Hama Dan Penyakit Pada Bunga Krisan Menggunakan Metode Forward Chaining 
yang nantinya akan membantu dan memudahkan para petani bunga krisan untuk mengetahui jenis penyakit yang di alami serta solusi cepat dan tepat untuk mengobatinya, sehingga dapat meminimalisasi kegagalan panen yang diakibatkan hama dan penyakit tersebut..

\section{METODOLOGI PENELITIAN}

Sistem pakar yang akan dibangun digunakan untuk mendiagnosa penyakit pada bunga krisan dengan metode forward chaining yang akan digunakan untuk mencocokkan gejala-gejala yang berupa pertanyaan yang nantinya akan dijwab oleh user dengan rule yang ada, kemudian akan didapatkan kesimpulan. Rule didapat dari kumpulan semua fakta yang merupakan gejala suatu penyakit tertentu kemudian dimasukkan kedalam aturan IF - THEN. Hasil output sistem berupa nama penyakit, pengobatan dan pengendalian. Gambaran sistem dapat dilihat pada gambar 1 berikut :

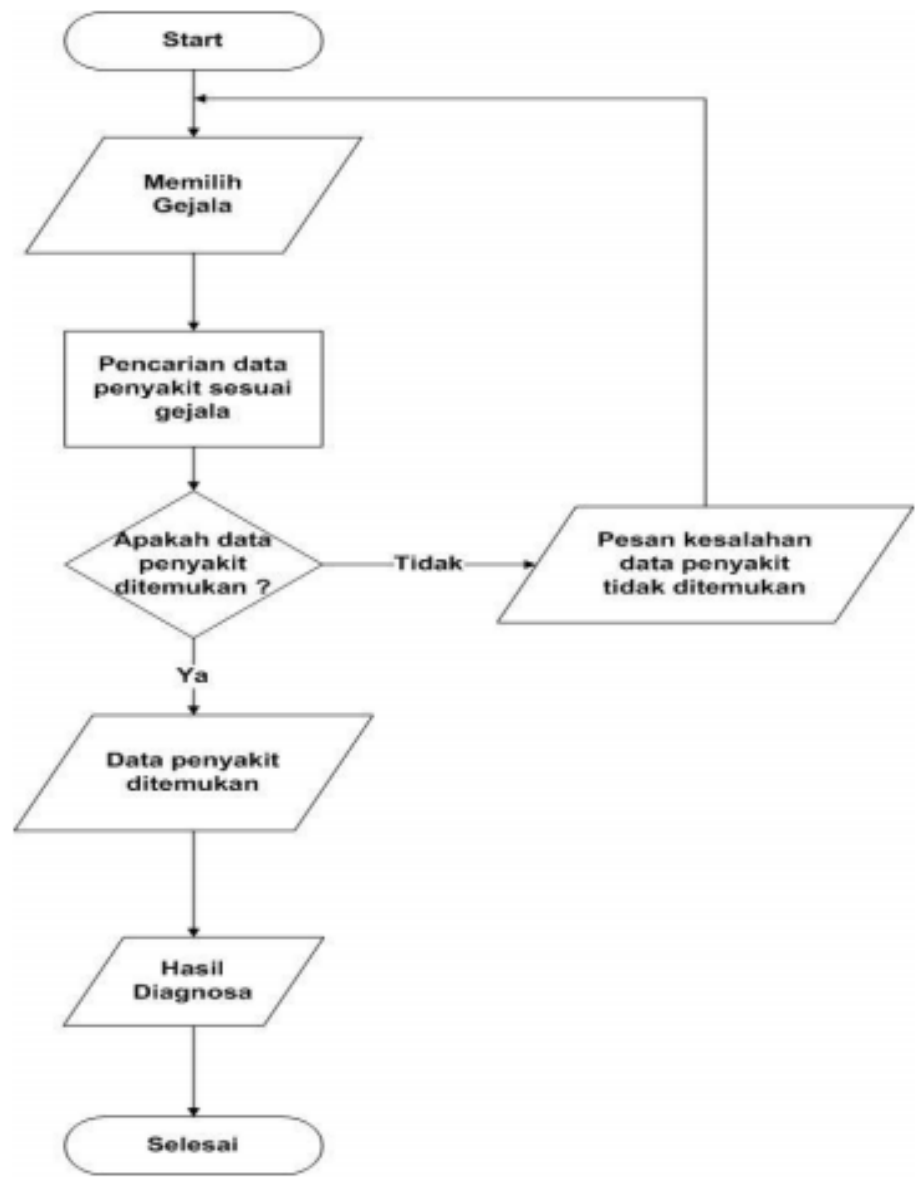

Gambar 1 Gambaran Sistem

Sistem pakar diagnose penyakit bunga krisan membutuhkan basis pengetahuan untuk membantu menentukan penyakit bunga krisan. Basis pengetahuan ini berisi data-data yang dibutuhkan oleh sistem, basis pengetahuan yang dibutuhkan sistem terdiri dari gejala-gejala,jenis penyakit, keterangan setiap penyakit, solusi pengobatan dan pencegahannya. Dalam perancangan basis pengetahuan ini menggunakan kaidah produksi sebagai sarana untuk representasi pengetahuan. Berdasarkan pakar bunga krisan yaitu Bapak Misnan yang berprofesi sebagai ketua kelompok tani di desa Poncokusumo kabupaten Malang. Terdapat beberapa penyakit bunga krisan dan gejala yang ditimbulkan serta penanganannya. Basis pengetahuan dimasukkan dalam program sehingga computer akan berperan sebagai ahli yang mampu mengidentifikasi jenis penyakit, gejala dan solusi pengobatan.

\section{DATA PENYAKIT}

Berikut data-data penyakit dan genjala pada bunga krisan yang terdapat pada tabel 1:

Tabel 1. Jenis Penyakit dan Gejala pada Tanaman Bunga Krisan

\begin{tabular}{|l|l|l|}
\hline No & \multicolumn{1}{|c|}{ Nama Penyakit } & \multicolumn{1}{c|}{ Gejala } \\
\hline 1 & Pengorok Daun & $\begin{array}{l}\text { Daun menguning } \\
\text { Bintik putih pada tanaman }\end{array}$ \\
\hline
\end{tabular}




\begin{tabular}{|c|c|c|}
\hline & & Adanya alur berliku bekas kotoran berwarna putih \\
\hline 2 & Thrips & $\begin{array}{l}\text { Pucuk dan tunas-tunas samping berwarna keperak-perakan } \\
\text { Daun menguning } \\
\text { Serangan pada daun bagian bawah/seluruh daun }\end{array}$ \\
\hline 3 & $\begin{array}{l}\text { Penyakit Karat/ } \\
\text { Karat Putih }\end{array}$ & $\begin{array}{l}\text { Daun kerdil } \\
\text { Serangan pada daun bagian bawah/seluruh daun } \\
\text { Daun cekung dan rapuh } \\
\text { Permukaan daun bagian bawah berbintil coklat }\end{array}$ \\
\hline 4 & Layu Fusarium & $\begin{array}{l}\text { Bercak coklat pada daun } \\
\text { Pertumbuhan bagian atas tanaman terhambat atau mati } \\
\text { Daun layu dan gugur }\end{array}$ \\
\hline 5 & & $\begin{array}{l}\text { Layu permanen } \\
\text { Tanaman membusuk atau mati }\end{array}$ \\
\hline 6 & $\begin{array}{l}\text { Embun Jelaga / Cendawan } \\
\text { Jelaga }\end{array}$ & $\begin{array}{l}\text { Serangan pada daun bagian bawah/seluruh daun } \\
\text { Daun tertutupi lapisan hitam seperti jelaga hitam }\end{array}$ \\
\hline 7 & Embun Tepung & $\begin{array}{l}\text { Permukaan daun tertutup dengan lapisan tepung putih } \\
\text { Daun menguning } \\
\text { Daun pucat }\end{array}$ \\
\hline 8 & Virus Kerdil & $\begin{array}{l}\text { Daun menguning } \\
\text { Tanaman mengerdil } \\
\text { Tidak membentuk tunas samping } \\
\text { Daun kerdil atau berkerut }\end{array}$ \\
\hline 9 & Kapang Daun & $\begin{array}{l}\text { Daun menguning } \\
\text { Daun kerdil atau berkerut } \\
\text { Gagal berbunga } \\
\text { Serangan pada daun bagian bawah/seluruh daun }\end{array}$ \\
\hline 10 & Bercak Daun & $\begin{array}{l}\text { Bercak coklat pada daun } \\
\text { Serangan pada daun bagian bawah/seluruh daun } \\
\text { Daun mengering dan menguning }\end{array}$ \\
\hline 11 & $\begin{array}{l}\text { Ulat } \\
\text { Tentara/Grayak }\end{array}$ & $\begin{array}{l}\text { Daun menguning } \\
\text { Epidermis atau bagian atas daun rusak/transparan } \\
\text { Tersisa hanya tulang daun pada tanaman } \\
\text { Hama memakan tunas dan bunga }\end{array}$ \\
\hline 12 & Hawar Daun & $\begin{array}{l}\text { Permukaan daun terdapat bercak-bercak coklat tidak beraturan } \\
\text { Daun rontok saat terkena angin }\end{array}$ \\
\hline 13 & $\begin{array}{l}\text { Busuk Pangkal } \\
\text { Batang }\end{array}$ & $\begin{array}{l}\text { Tanaman layu } \\
\text { Daun menguning terutama daun bagian bawah } \\
\text { Perbatasan pangkal batang dengan akar terjadi pembusukan } \\
\text { yang berwarna kehitaman }\end{array}$ \\
\hline
\end{tabular}

Jumlah penyakit yang diolah dalam sistem pakar penyakit bunga krisan adalah sebanyak 12 penyakit yang sering dialami bunga krisan di Desa Poncokusumo. Jika data penyakit bunga krisan dijadikan bentuk kode maka akan menjadi kode yang ditampilkan pada table 2:

Tabel 2. Tabel Kode Penyakit pada Bunga Krisan

\begin{tabular}{|l|l|}
\hline Kode & \multicolumn{1}{|c|}{ Nama Penyakit } \\
\hline P001 & Penggorok Daun \\
\hline P002 & Thrips \\
\hline P003 & Penyakit Karat / Karat Putih \\
\hline P004 & Layu Fusarium \\
\hline P005 & Embun Jelaga / Cendawan Jelaga \\
\hline P006 & Embun Tepung \\
\hline P007 & Virus Kerdil \\
\hline P008 & Kapang Daun \\
\hline P009 & Bercak Daun \\
\hline P010 & Ulat Tentara / Grayak \\
\hline P011 & Hawar Daun \\
\hline
\end{tabular}




\section{P012 $\quad$ Busuk Pangkal Batang}

\section{DATA GEJALA}

Data-data gejala yang digunakan dalam sistem pakar penyakit bungak krisan ini berjumlah 30 gejala. Data gejala jadikan bentuk kode seperti yang ditunjukkan pada table 3:

Tabel 3. Tabel Kode Gejala pada Bunga Krisan

\begin{tabular}{|c|c|}
\hline Kode & Nama Penyakit \\
\hline G001 & Daun menguning \\
\hline G002 & Bintik putih pada tanaman \\
\hline G003 & Adanya alur berliku bekas kotoran berwarna putih \\
\hline G004 & Pucuk dan tunas-tunas samping berwarna keperak-perakan \\
\hline G005 & Serangan pada daun bagian bawah/seluruh daun \\
\hline G006 & Daun kerdil \\
\hline G007 & Daun cekung dan rapuh \\
\hline G008 & Permukaan daun bagian bawah berbintil coklat \\
\hline G009 & Bercak coklat pada daun \\
\hline G010 & Pertumbuhan bagian atas tanaman terhambat atau mati \\
\hline G011 & Daun layu dan gugur \\
\hline G012 & Layu permanen \\
\hline G013 & Tanaman membusuk atau mati \\
\hline G014 & Daun tertutupi lapisan hitam seperti jelaga hitam \\
\hline G015 & Permukaan daun tertutup dengan lapisan tepung putih \\
\hline G016 & Daun pucat \\
\hline G017 & Tanaman mengerdil \\
\hline G018 & Tidak membentuk tunas samping \\
\hline G019 & Berbunga lebih awal dari tanaman sehat \\
\hline G020 & Gagal berbunga \\
\hline G021 & Daun mongering \\
\hline G022 & Epidermis atau bagian atas daun rusak/transparan \\
\hline G023 & Tersisa hanya tulang daun pada tanaman \\
\hline G024 & Hama memakan tunas danbunga \\
\hline G025 & Permukaan daun terdapat bercak-bercak coklat tidak beraturan \\
\hline G026 & Daun rontok saat terkena angin \\
\hline G027 & tanaman layu \\
\hline G028 & daun menguning terutama daun bagian bawah \\
\hline G029 & $\begin{array}{l}\text { Perbatasan pangkal batang dengan akar terjadi pembusukan yang berwarna } \\
\text { kehitaman }\end{array}$ \\
\hline
\end{tabular}

\section{POHON KEPUTUSAN}

Proses pencarian dari pohon keputusan menggunakan pencarian algoritma teknik best first search. Pencarian jenis ini dikenal juga sebagai heuristic. Pendekatan yang dilakukan adalah mencari solusi yang terbaik berdasarkan pengetahuan yang dimiliki sehingga penelusuran dapat ditentukan harus dimulai dari mana dan bagaimana proses terbaik untuk mencari solusi. Pohon keputusan terdiri dari gejala penyakit,dan garis penghubung yang menunjukkan hubungan antar objek. Pohon keputusan ditunjukkan pada gambar 2. 


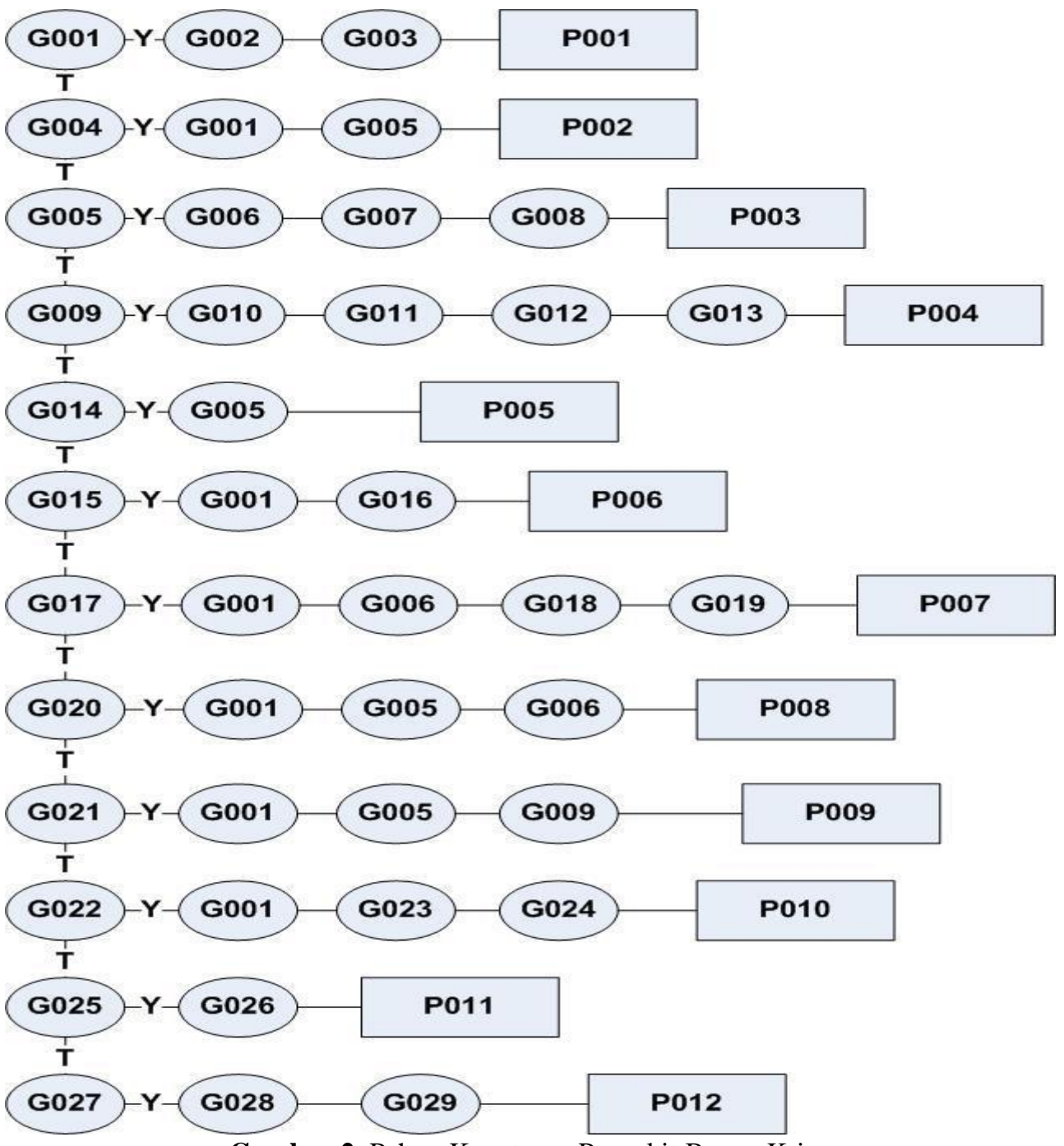

Gambar 2. Pohon Keputusan Penyakit Bunga Krisan

\section{TABEL KEPUTUSAN}

Berdasarkan pengetahuan yang berupa data gejala dan penyakit pada bunga krisan, maka dapat dibuat basis pengetahuan berupa hubungan atau keterkaitan yang ada antara gejala-gejala dan penyakit yang nantinya akan menghasilkan sebuah kesimpulan pada tabel keputusan seperti ditunjukkan pada tabel 4 sebagai berikut:

Tabel 4. Tabel Keputusan

\begin{tabular}{|c|c|c|c|c|c|c|c|c|c|c|c|c|}
\hline \multirow{2}{*}{ Gejala } & \multicolumn{90}{|c|}{ Penyakit } \\
\cline { 2 - 12 } & P001 & P002 & P003 & P004 & P005 & P006 & P007 & P008 & P009 & P010 & P011 & P012 \\
\hline G001 & Ya & Ya & & & & Ya & Ya & Ya & Ya & Ya & & \\
\hline G002 & Ya & & & & & & & & & & & \\
\hline G003 & Ya & & & & & & & & & & & \\
\hline G004 & & Ya & & & & & & & & & & \\
\hline
\end{tabular}




\begin{tabular}{|c|c|c|c|c|c|c|c|c|c|}
\hline G005 & $\mathrm{Ya}$ & $\mathrm{Ya}$ & & $\mathrm{Ya}$ & & $\mathrm{Ya}$ & $\mathrm{Ya}$ & & \\
\hline G006 & & $\mathrm{Ya}$ & & & $\mathrm{Ya}$ & $\mathrm{Ya}$ & & & \\
\hline G007 & & $\mathrm{Ya}$ & & & & & & & \\
\hline G008 & & $\mathrm{Ya}$ & & & & & & & \\
\hline G009 & & & $\mathrm{Ya}$ & & & & $\mathrm{Ya}$ & & \\
\hline G010 & & & $\mathrm{Ya}$ & & & & & & \\
\hline G011 & & & $\mathrm{Ya}$ & & & & & $\mathrm{Ya}$ & \\
\hline G012 & & & $\mathrm{Ya}$ & & & & & & $\mathrm{Ya}$ \\
\hline G013 & & & $\mathrm{Ya}$ & & & & & & \\
\hline G014 & & & & $\mathrm{Ya}$ & & & & & \\
\hline
\end{tabular}

Berdasarkan informasi tersebut maka disusun sebanyak 12 rule base yang berkaitan dengan jenis penyakit yang sering dikeluhkan oleh para petani bunga krisan, rule base tersebut adalah sebagai berikut

Tabel 5. Tabel Rulebase

\begin{tabular}{|c|c|}
\hline Rule ke- & Rules \\
\hline 1 & $\begin{array}{l}\text { IF Daun menguning AND(Bintik putih pada tanaman OR Adanya alur berliku bekas } \\
\text { kotoran berwarna putih) THEN Pengorok daun }\end{array}$ \\
\hline 2 & $\begin{array}{l}\text { IF Pucuk dan tunas-tunas samping berwarna keperak-perakan AND (Daun } \\
\text { menguning OR Serangan pada daun bagian bawah/seluruh daun) THEN Thrips }\end{array}$ \\
\hline 3 & $\begin{array}{l}\text { IF Serangan pada daun bagian bawah/seluruh daun AND Daun Kerdil AND (Daun } \\
\text { cekung dan rapuh OR Permukaan daun bagian bawah berbintil coklat) THEN } \\
\text { penyakit karat/Karat putih }\end{array}$ \\
\hline 4 & $\begin{array}{c}\text { IF Bercak coklat pada daunAND Pertumbuhan bagian atas tanaman terhambat atau } \\
\text { mati AND Daun layu dan gugur AND (Layu permanen OR Tanaman membusuk } \\
\text { atau mati) THEN Layu Fusarium }\end{array}$ \\
\hline 5 & $\begin{array}{c}\text { IF Daun tertutupi lapisan hitam seperti jelaga hitam Serangan pada daun bagian } \\
\text { bawah/seluruh daun ORTHEN Embun jelaga/Cendawan jelaga }\end{array}$ \\
\hline 6 & $\begin{array}{l}\text { IF Permukaan daun tertutup dengan lapisan tepung putih AND (Daun menguning } \\
\text { OR Daun pucat) THEN Embun Tepung }\end{array}$ \\
\hline 7 & $\begin{array}{c}\text { IF Daun menguning AND tanaman mengerdil AND Tidak membentuk tunas } \\
\text { samping AND(Berbunga lebih awal dari tanaman sehat OR Daun kerdil atau } \\
\text { berkerut)THEN Virus kerdil }\end{array}$ \\
\hline
\end{tabular}




\begin{tabular}{|c|c|}
\hline 8 & $\begin{array}{r}\text { IF Daun menguning AND Daun kerdil atau berkerut AND(Gagal berbunga OR } \\
\text { Serangan pada daun bagian bawah/seluruh daun) THEN Kapang daun }\end{array}$ \\
\hline 9 & $\begin{array}{r}\text { IF Bercak coklat pada daun AND Serangan pada daun bagian bawah/seluruh daun } \\
\text { AND (Daun mongering OR Daun menguning) THEN Bercak daun }\end{array}$ \\
\hline 10 & $\begin{array}{r}\text { IF Daun menguning AND Epidermis atau bagian atas daun rusak/transparan } \\
\text { AND (Tersisa hanya tulang daun pada tanaman OR Hama memakan tunas dan } \\
\text { bunga) THEN Ulat tentara/grayak }\end{array}$ \\
\hline 11 & $\begin{array}{r}\text { IF permukaan daun terdapat bercak-bercak coklat tidak beraturan OR Daun rontok } \\
\text { saat terkena angin THEN Hawar Daun }\end{array}$ \\
\hline 12 & $\begin{array}{r}\text { IF tanaman layu AND (daun menguning terutama daun bagian bawah OR } \\
\text { perbatasan pangkal batang dengan akar terjadi pembusukan yang berwarna } \\
\text { kehitaman) THEN Busuk Pangkal Batang }\end{array}$ \\
\hline
\end{tabular}

Dari tabel 5 di atas dapat dibuat tabel rule dalam bentuk kode seperti pada tabel 6 yaitu tabel rule dalam bentuk kode:

Tabel 6. Tabel Rule dalam bentuk Kode

\begin{tabular}{|l|l|}
\hline Rule ke- & \multicolumn{1}{|c|}{ Rule } \\
\hline 1. & IFG001AND (G002OR G003)THENP001 \\
\hline 2. & IFG004AND (G001OR G005)THENP002 \\
\hline 3. & IFG005AND G006 AND (G007OR G008) THEN P003 \\
\hline 4. & IF G009AND G010 AND G011 AND (G012 OR G013) THENP004 \\
\hline 5. & IF G014 ORG005THEN P005 \\
\hline 6. & IF G015 AND(G001ORG016)THENP006 \\
\hline 7. & IF G017ANDG001AND G006 AND (G018 OR G019) THEN P007 \\
\hline 8. & IF G020 AND G001 AND(G005 ORG006) THEN P008 \\
\hline 9. & IF G021 AND G001 AND(G005 ORG009) THEN P009 \\
\hline 10. & IF G022 AND G001 AND(G023 ORG024) THEN P010 \\
\hline 11. & IF G025 ORG026THEN P011 \\
\hline 12 & IF G027 AND(G028ORG029)THENP012 \\
\hline
\end{tabular}

\section{PEMODELAN SISTEM}

Pemodelan system dalam bentuk flowchat yang dapat ditunjukkan pada gambar 3 di bawah. Flowchart sistem mulai dari user memilih menu form, kemudian menuju ke menu konsultasi, dari menu konsultasi menjawab pertanyaan sistem. Dari pertanyaan sistem kemudian user memilih dan jawaban akan diproses, langkah tersebut bisa dilihat pada gambar 3. 


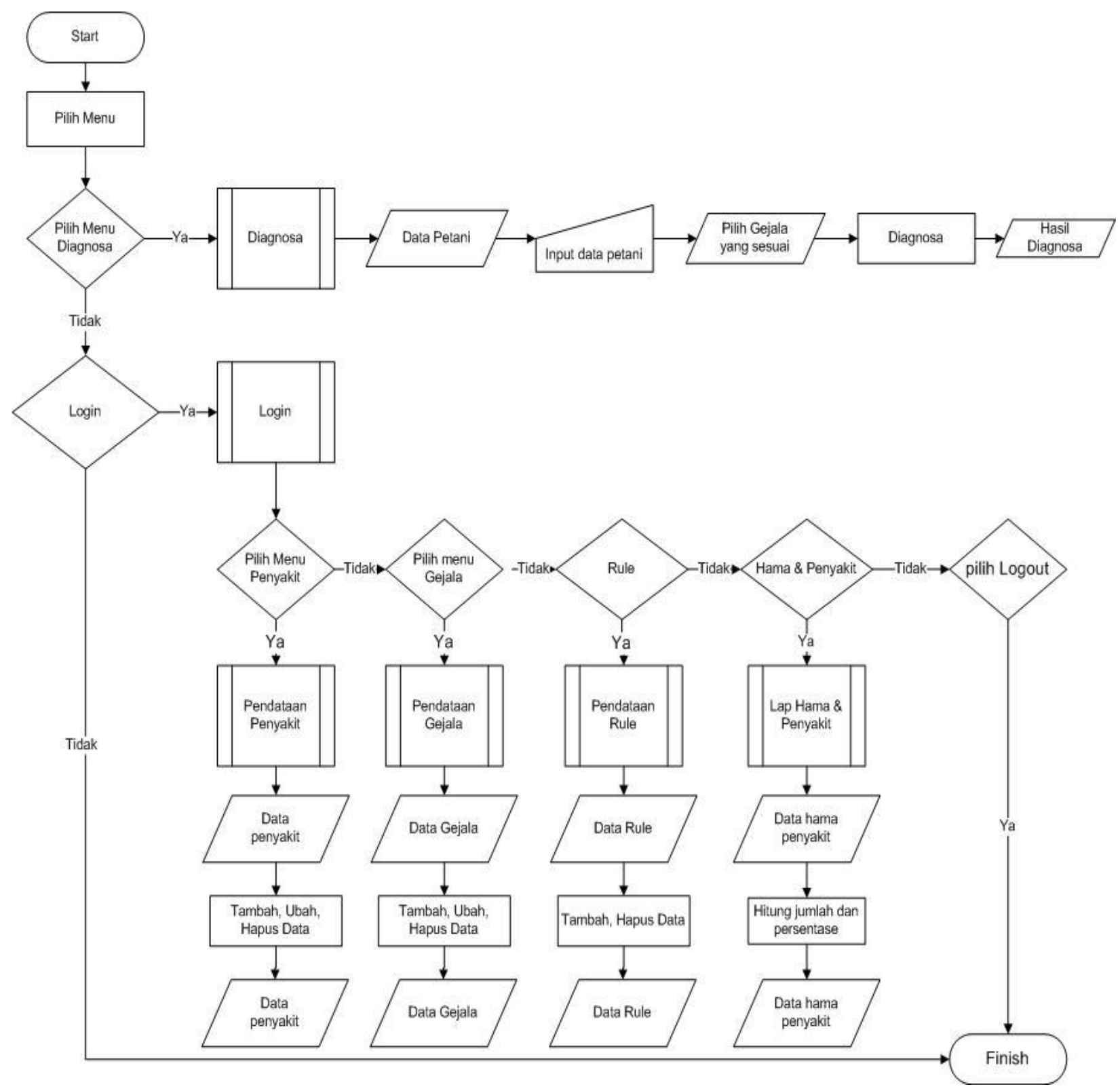

Gambar 3. Pohon Keputusan Penyakit Bunga Krisan

\section{HASIL DAN PEMBAHASAN}

a) Implementasi Antarmuka Pengguna

Sesuai dengan perancangan sistem yang akan dibahas sebelumnya, ada halaman untuk akses user dan admin, untuk halaman admin dapat diakses oleh administrator dan untuk user hanya bisa mengakses hanya sebagian halaman yang akan diberikan oleh system

\section{Halaman Login Admin}

Sebelum admin dapat mengakses halaman sistem seluruhnya, serorang administrator harus login terlebih dahulu dengan memasukkan Username dan password, berikut ini adalah tampilan halaman login pada gambar 4 di bawah ini. 


\section{Sistem Pakar}

Metode Forward Chaining

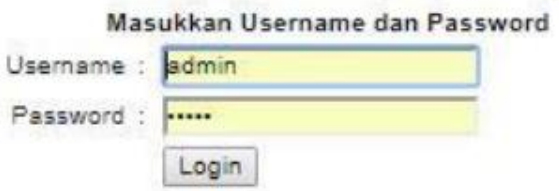

Kembal

Sistem Pakar Diagnosa Hama dan Penyakit Bunga Krisan

Copynght Aø 2018. AsiA Malang

Gambar 4. Halaman Login

\section{Halaman Penyakit}

Setelah halaman admin tampil maka admin dapat melihat daftar semua hama dan penyakit di halaman penyakit. Halaman penyakit ini akan menampilkan macam-macam penyakit beserta keterangan dan solusinya. Berikut ini adalah tampilan halaman penyakit pada gambar.

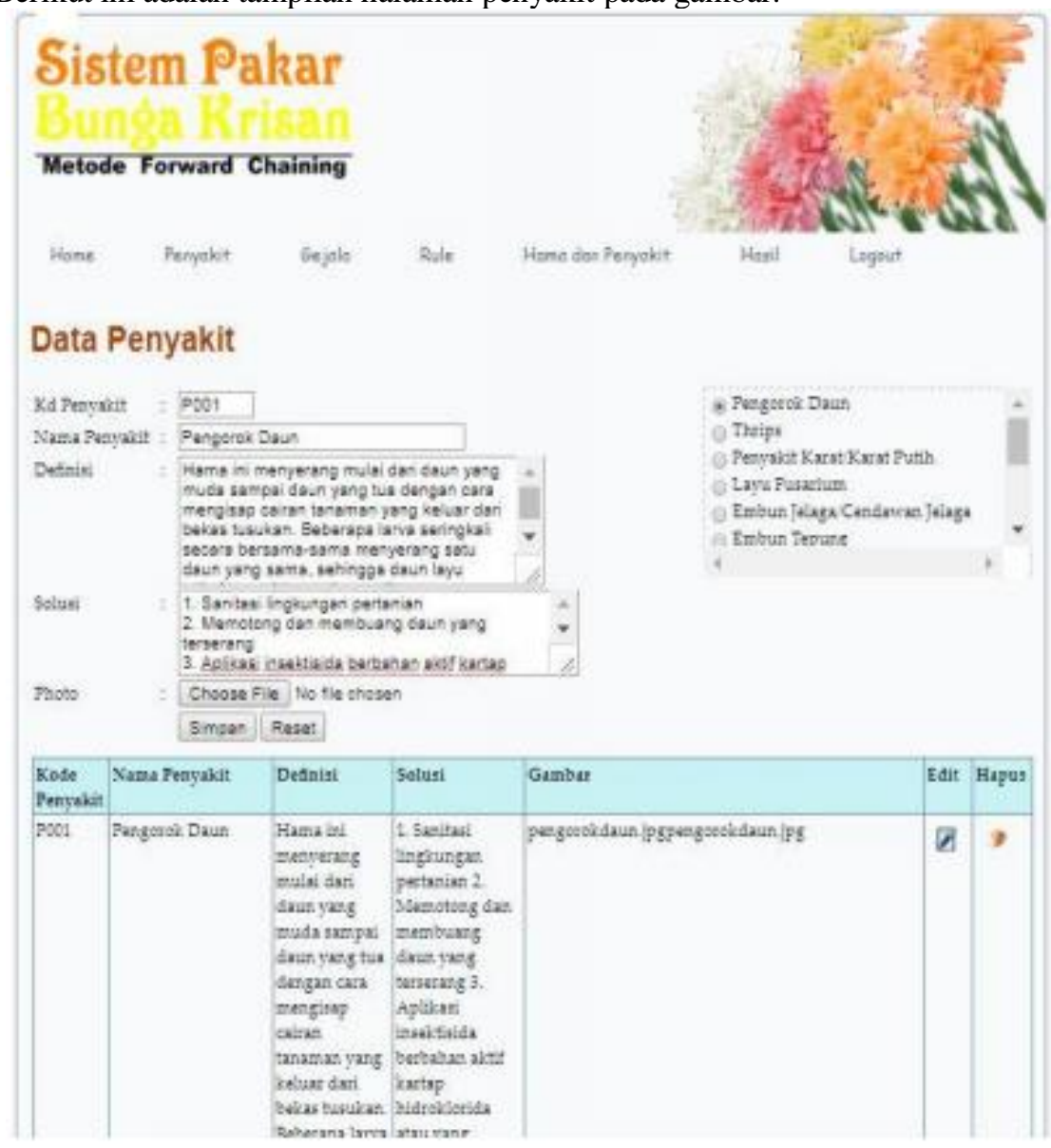

Gambar 5. Halaman Penyakit dan Hama

\section{Halaman Diagnosa}

Pada halaman Setelah menjawab pertanyaan yang diberikan oleh sistem sesuai rule, maka akan ditemukan hasil dari diagnosa penyakit berdasarkan jawaban dari user. Pada hasil diagnosa akan ditampilkan kembali gejala-gejala yang dipilih tersebut. Berikut adalah tampilan halaman hasil diagnose. 


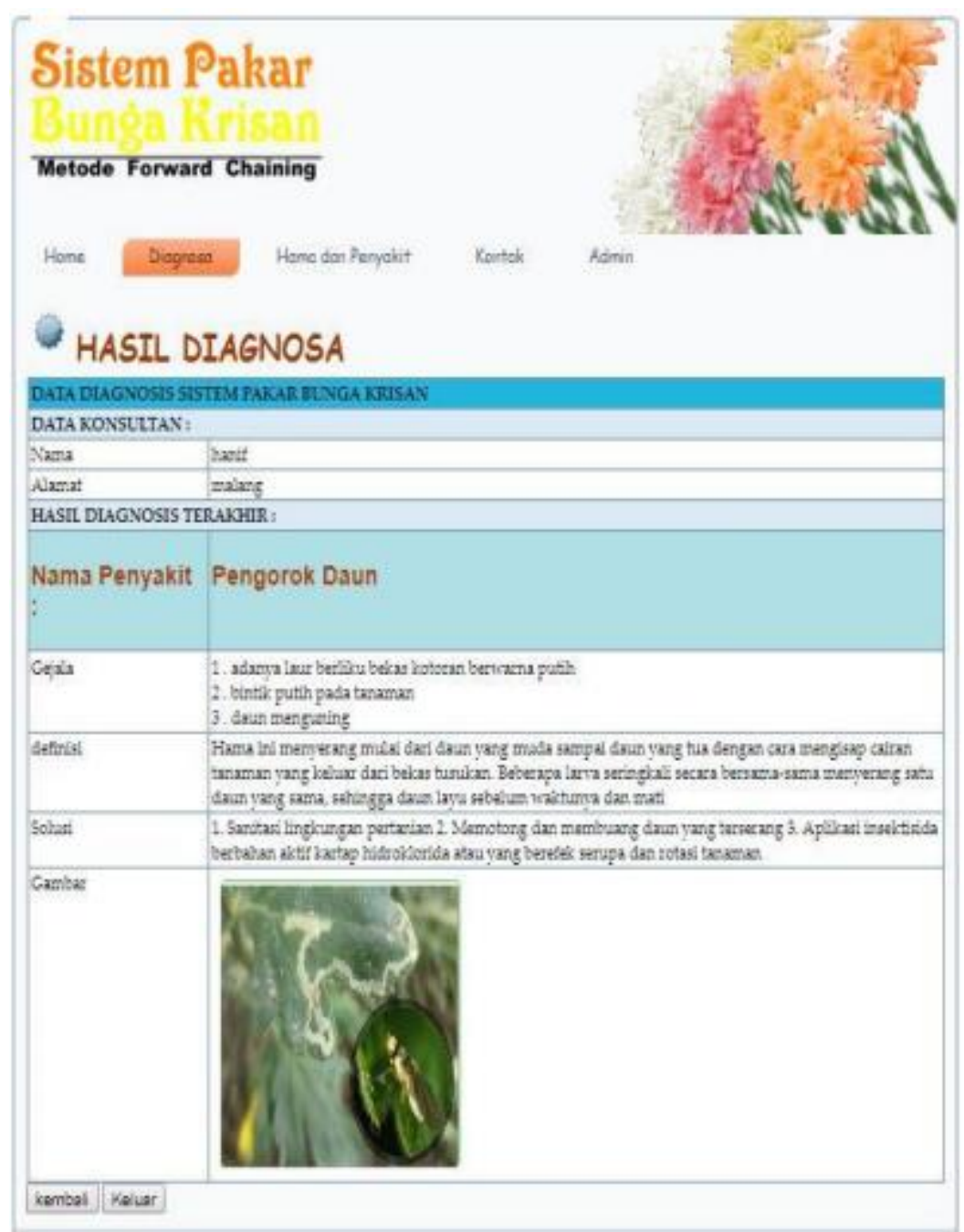

Gambar 6. Halaman hasil diagnosa

\section{b) Pengujian Sistem}

pengujian akan dilakukan sebanyak 21 kali dimana user akan melakukan konsultasi dengan menjawab beberapa pertanyaan tentang gejala-gejala yang telah dialami.

\begin{tabular}{|c|c|c|c|c|c|c|}
\hline No & Nama & $\begin{array}{c}\text { Gejala Yang Dialami } \\
\text { Petani }\end{array}$ & Rule Gejala Sistem & Sistem & Pakar & Hasil \\
\hline \multirow{3}{*}{1} & \multirow{3}{*}{$\begin{array}{l}\text { Bpk. } \\
\text { Ketut }\end{array}$} & Daun menguning & Daun Menguning & \multirow{3}{*}{ Thrips } & \multirow{3}{*}{ Thrips } & \multirow{3}{*}{ Sesuai } \\
\hline & & $\begin{array}{l}\text { Pucuk dan tunastunas } \\
\text { samping berwarna } \\
\text { keperakan }\end{array}$ & $\begin{array}{l}\text { Pucuk dan tunas tunas } \\
\text { samping berwarna } \\
\text { keperakan }\end{array}$ & & & \\
\hline & & & $\begin{array}{l}\text { Serangan pada daun bagian } \\
\text { bawah/seluruh daun }\end{array}$ & & & \\
\hline \multirow{4}{*}{2} & \multirow{4}{*}{$\begin{array}{l}\text { Bpk. } \\
\text { Ketut }\end{array}$} & $\begin{array}{l}\text { Serangan pada daun } \\
\text { bagian bawah/seluruh } \\
\text { daun }\end{array}$ & $\begin{array}{l}\text { Serangan pada daun bagian } \\
\text { bawah/seluruh daun }\end{array}$ & \multirow{4}{*}{$\begin{array}{l}\text { Penyakit } \\
\text { karat } \\
\text { putih }\end{array}$} & \multirow{4}{*}{$\begin{array}{l}\text { Penyakit } \\
\text { karat } \\
\text { putih }\end{array}$} & \multirow{4}{*}{ Sesuai } \\
\hline & & $\begin{array}{l}\text { Daun Cekung dan } \\
\text { rapuh }\end{array}$ & Daun Cekung dan rapuh & & & \\
\hline & & Daun Kerdil & Daun Kerdil & & & \\
\hline & & $\begin{array}{l}\text { Permukaan daun } \\
\text { bawah berbintil coklat }\end{array}$ & $\begin{array}{l}\text { Permukaan daun bawah } \\
\text { berbintil coklat }\end{array}$ & & & \\
\hline
\end{tabular}




\begin{tabular}{|c|c|c|c|c|c|c|}
\hline \multirow{4}{*}{3} & \multirow{4}{*}{$\begin{array}{l}\text { Bpk. } \\
\text { Ketut }\end{array}$} & Daun Menguning & Daun Menguning & \multirow{4}{*}{$\begin{array}{l}\text { Tidak } \\
\text { Diketahu } \\
\quad \mathrm{i}\end{array}$} & \multirow{4}{*}{$\begin{array}{l}\text { Virus } \\
\text { Kerdil }\end{array}$} & \multirow{4}{*}{$\begin{array}{l}\text { Tidak } \\
\text { Sesuai }\end{array}$} \\
\hline & & Daun Kerdil & Daun Kerdil & & & \\
\hline & & Tanaman Mengerdil & Daun Cekung dan rapuh & & & \\
\hline & & $\begin{array}{l}\text { Berbunga lebih awal } \\
\text { daripada bunga } \\
\text { lainnya }\end{array}$ & $\begin{array}{l}\text { Berbunga lebih awal dari } \\
\text { tanaman sehat }\end{array}$ & & & \\
\hline \multirow{4}{*}{4} & \multirow{4}{*}{$\begin{array}{l}\text { Bpk. } \\
\text { Ali }\end{array}$} & $\begin{array}{l}\text { Pertumbuhan bagian } \\
\text { atas tanaman } \\
\text { terhambat atau mati }\end{array}$ & Bercak coklat pada daun & \multirow{4}{*}{$\begin{array}{l}\text { Layu } \\
\text { fusarium }\end{array}$} & \multirow{4}{*}{$\begin{array}{l}\text { Layu } \\
\text { fusarium }\end{array}$} & \multirow{4}{*}{ Sesuai } \\
\hline & & $\begin{array}{l}\text { Bercak coklat pada } \\
\text { daun }\end{array}$ & $\begin{array}{l}\text { Pertumbuhan bagian atas } \\
\text { tanaman terhambat atau } \\
\text { mati }\end{array}$ & & & \\
\hline & & Daun layu dan gugur & Daun layu dan gugur & & & \\
\hline & & & Layu permanen & & & \\
\hline \multirow{3}{*}{5} & \multirow{3}{*}{$\begin{array}{l}\text { Bpk. } \\
\text { Ali }\end{array}$} & $\begin{array}{l}\text { Permukaan daun } \\
\text { tertutup dengan } \\
\text { lapisan tepung putih }\end{array}$ & Daun menguning & \multirow{3}{*}{$\begin{array}{l}\text { Embun } \\
\text { tepung }\end{array}$} & \multirow{3}{*}{$\begin{array}{l}\text { Embun } \\
\text { tepung }\end{array}$} & \multirow{3}{*}{ Sesuai } \\
\hline & & Daun menguning & $\begin{array}{l}\text { Permukaan daun tertutup } \\
\text { dengan lapisan tepung putih }\end{array}$ & & & \\
\hline & & Daun pucat & Daun pucat & & & \\
\hline \multirow{4}{*}{6} & \multirow{4}{*}{$\begin{array}{l}\text { Bpk. } \\
\text { Fauzi }\end{array}$} & Daun menguning & Daun menguning & \multirow{4}{*}{$\begin{array}{l}\text { Ulat } \\
\text { tentara/G } \\
\text { rayak }\end{array}$} & \multirow{4}{*}{$\begin{array}{l}\text { Ulat } \\
\text { tentara/G } \\
\text { rayak }\end{array}$} & \multirow{4}{*}{ Sesuai } \\
\hline & & $\begin{array}{l}\text { Hama memakan tunas } \\
\text { dan bunga }\end{array}$ & $\begin{array}{l}\text { Epidermis atau bagian atas } \\
\text { daun rusak/transparan }\end{array}$ & & & \\
\hline & & $\begin{array}{l}\text { Tersisa hanya tulang } \\
\text { daun pada tanaman }\end{array}$ & $\begin{array}{l}\text { Tersisa hanya tulang daun } \\
\text { pada tanaman }\end{array}$ & & & \\
\hline & & $\begin{array}{l}\text { Epidermis atau bagian } \\
\text { atas daun } \\
\text { rusak/transparan }\end{array}$ & $\begin{array}{l}\text { Hama memakan tunas dan } \\
\text { bunga }\end{array}$ & & & \\
\hline \multirow[b]{2}{*}{7} & \multirow[b]{2}{*}{$\begin{array}{l}\text { Bpk. } \\
\text { Fauzi }\end{array}$} & tanaman layu & tanaman layu & \multirow[b]{2}{*}{$\begin{array}{l}\text { Busuk } \\
\text { pangkal } \\
\text { batang }\end{array}$} & \multirow[b]{2}{*}{$\begin{array}{l}\text { Busuk } \\
\text { pangkal } \\
\text { batang }\end{array}$} & \multirow[b]{2}{*}{$\begin{array}{l}\text { Tidak } \\
\text { Sesuai }\end{array}$} \\
\hline & & $\begin{array}{l}\text { perbatasan pangkal } \\
\text { batang dengan akar } \\
\text { terjadi }\end{array}$ & $\begin{array}{l}\text { daun menguning terutama } \\
\text { daun bagian bawah }\end{array}$ & & & \\
\hline \multirow{4}{*}{8} & \multirow{4}{*}{$\begin{array}{l}\text { Bpk. } \\
\text { Sugeng }\end{array}$} & $\begin{array}{l}\text { Serangan pada daun } \\
\text { bagian bawah/seluruh } \\
\text { daun }\end{array}$ & Daun menguning & \multirow{4}{*}{$\begin{array}{l}\text { Kapang } \\
\text { Daun/Ke } \\
\text { labu }\end{array}$} & \multirow{4}{*}{$\begin{array}{l}\text { Kapang } \\
\text { Daun/Ke } \\
\text { labu }\end{array}$} & \multirow{4}{*}{ Sesuai } \\
\hline & & Daun menguning & $\begin{array}{l}\text { Serangan pada daun bagian } \\
\text { bawah/seluruh daun }\end{array}$ & & & \\
\hline & & Daun kerdil & Daun kerdil & & & \\
\hline & & Gagal berbunga & Gagal berbunga & & & \\
\hline \multirow{5}{*}{9} & \multirow{5}{*}{$\begin{array}{l}\text { Bpk. } \\
\text { Sugeng }\end{array}$} & Tanaman mengerdil & Tanaman mengerdil & & & \\
\hline & & Daun menguning & Daun menguning & & & \\
\hline & & Daun kerdil & Daun kerdil & & & \\
\hline & & $\begin{array}{l}\text { Tidak membentuk } \\
\text { tunas samping }\end{array}$ & $\begin{array}{l}\text { Tidak membentuk tunas } \\
\text { samping }\end{array}$ & kerdil & kerdil & Sesuai \\
\hline & & $\begin{array}{l}\text { Berbunga lebih awal } \\
\text { dari tanaman lain }\end{array}$ & $\begin{array}{l}\text { Berbunga lebih awal dari } \\
\text { tanaman lain }\end{array}$ & & & \\
\hline 10 & $\begin{array}{c}\text { Bpk } \\
\text { Sugeng }\end{array}$ & $\begin{array}{l}\text { Pucuk dan tunas-tunas } \\
\text { samping berwarna } \\
\text { keperak-perakan }\end{array}$ & $\begin{array}{l}\text { Pucuk dan tunas-tunas } \\
\text { samping berwarna keperak- } \\
\text { perakan }\end{array}$ & Thrips & Thrips & Sesuai \\
\hline
\end{tabular}




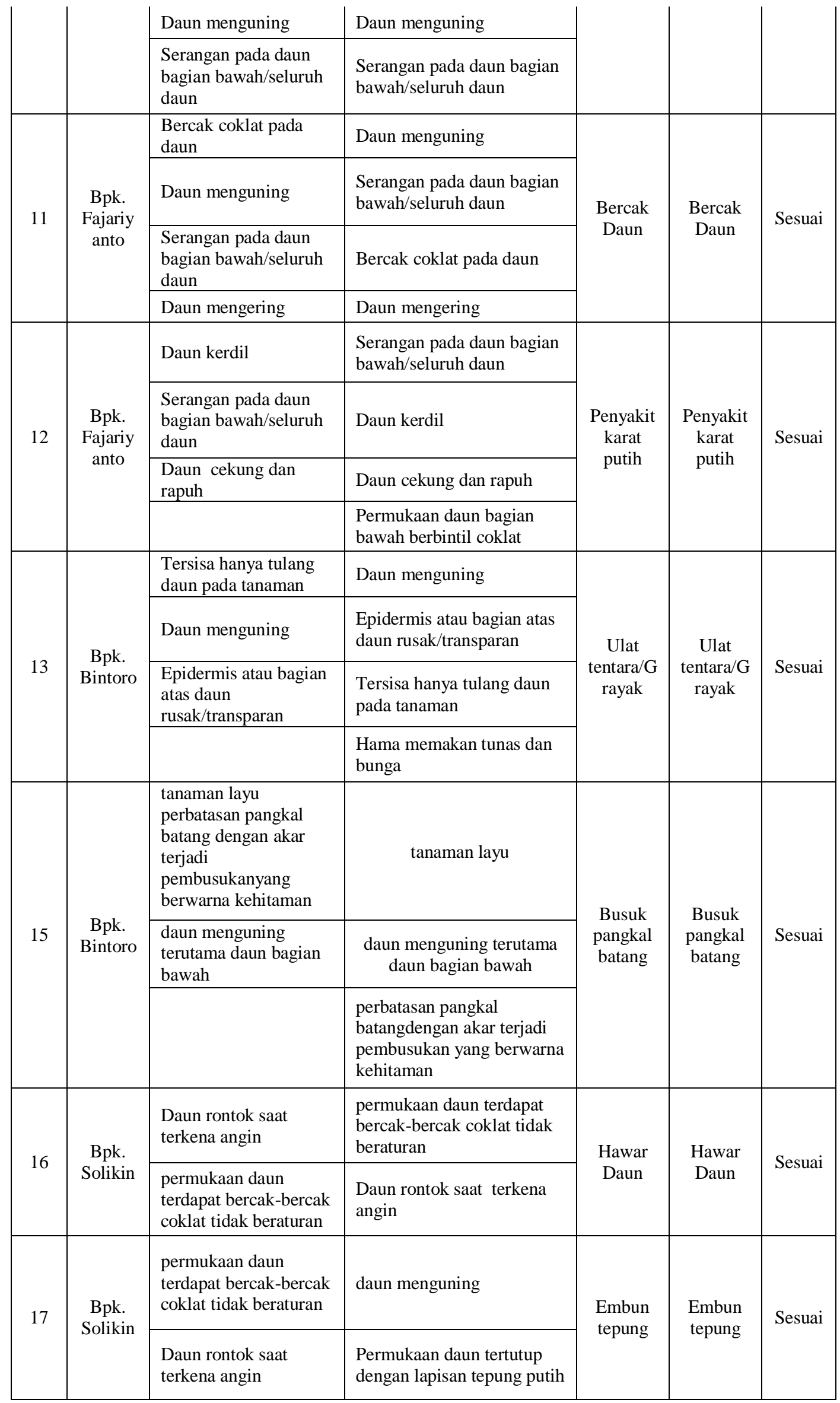




\begin{tabular}{|c|c|c|c|c|c|c|}
\hline & & daun menguning & Daun pucat & & & \\
\hline \multirow{2}{*}{18} & \multirow{2}{*}{$\begin{array}{l}\text { Bpk. } \\
\text { Solikin }\end{array}$} & $\begin{array}{l}\text { Serangan pada daun } \\
\text { bagian bawah/seluruh } \\
\text { daun }\end{array}$ & $\begin{array}{l}\text { Serangan pada daun bagian } \\
\text { bawah/seluruh daun }\end{array}$ & \multirow{2}{*}{$\begin{array}{l}\text { Embun } \\
\text { Jelaga / } \\
\text { Cendawa } \\
\text { n Jelaga }\end{array}$} & \multirow{2}{*}{$\begin{array}{l}\text { Embun } \\
\text { Jelaga / } \\
\text { Cendawa } \\
\text { n Jelaga }\end{array}$} & \multirow{2}{*}{ Sesuai } \\
\hline & & $\begin{array}{l}\text { Daun tertutupi lapisan } \\
\text { hitam seperti jelaga } \\
\text { hitam }\end{array}$ & $\begin{array}{l}\text { Daun tertutupi lapisan } \\
\text { hitam seperti jelaga hitam }\end{array}$ & & & \\
\hline \multirow{4}{*}{19} & \multirow{4}{*}{$\begin{array}{l}\text { Bpk. } \\
\text { Thaib }\end{array}$} & $\begin{array}{l}\text { Bercak coklat pada } \\
\text { daun }\end{array}$ & Daun menguning & \multirow{4}{*}{$\begin{array}{l}\text { Bercak } \\
\text { Daun }\end{array}$} & \multirow{4}{*}{$\begin{array}{c}\text { Bercak } \\
\text { Daun }\end{array}$} & \multirow{4}{*}{ Sesuai } \\
\hline & & Daun menguning & $\begin{array}{l}\text { Serangan pada daun bagian } \\
\text { bawah/seluruh daun }\end{array}$ & & & \\
\hline & & $\begin{array}{l}\text { Serangan pada daun } \\
\text { bagian bawah/seluruh } \\
\text { daun }\end{array}$ & Bercak coklat pada daun & & & \\
\hline & & & Daun mengering & & & \\
\hline \multirow{4}{*}{20} & \multirow{4}{*}{$\begin{array}{l}\text { Bpk. } \\
\text { Thaib }\end{array}$} & $\begin{array}{l}\text { Pertumbuhan bagian } \\
\text { atas tanaman } \\
\text { terhambat atau mati }\end{array}$ & Bercak coklat pada daun & \multirow{4}{*}{$\begin{array}{l}\text { Layu } \\
\text { fusarium }\end{array}$} & \multirow{4}{*}{$\begin{array}{l}\text { Layu } \\
\text { fusarium }\end{array}$} & \multirow{4}{*}{ Sesuai } \\
\hline & & $\begin{array}{l}\text { Bercak coklat pada } \\
\text { daun }\end{array}$ & $\begin{array}{l}\text { Pertumbuhan bagian atas } \\
\text { tanaman terhambat atau } \\
\text { mati }\end{array}$ & & & \\
\hline & & Daun layu dan gugur & Daun layu dan gugur & & & \\
\hline & & Layu permanen & Layu permanen & & & \\
\hline \multirow{3}{*}{21} & \multirow{3}{*}{$\begin{array}{l}\text { Bpk. } \\
\text { Thaib }\end{array}$} & $\begin{array}{l}\text { Pucuk dan tunas-tunas } \\
\text { samping berwarna } \\
\text { keperak-perakan }\end{array}$ & $\begin{array}{l}\text { Pucuk dan tunas-tunas } \\
\text { samping berwarna keperak- } \\
\text { perakan }\end{array}$ & \multirow{3}{*}{ Thrips } & \multirow{3}{*}{ Thrips } & \multirow{3}{*}{ Sesuai } \\
\hline & & Daun menguning & Daun menguning & & & \\
\hline & & $\begin{array}{l}\text { Serangan pada daun } \\
\text { bagian bawah/seluruh } \\
\text { daun }\end{array}$ & $\begin{array}{l}\text { Serangan pada daun bagian } \\
\text { bawah/seluruh daun }\end{array}$ & & & \\
\hline
\end{tabular}

Dari 21 pengujian di atas dimana user melakukan konsultasi dengan menjawab beberapa pertanyaan tentang gejala-gejala yang telah dialami didapatkan 19 pengujian sesuai dengan pakar dan 2 pengujian tidak sesuai dengan pakar, berdasarkan hasil pengujian yang telah dilakukan pada sistem pakar sebanyak 21 kali, nilai akurasi yang didapat sebanyak $90.48 \%$ sesuai dengan jawaban yang didapatkan dari pakar

\section{KESIMPULAN DAN SARAN}

Berdasarkan hasil perancangan dan pembahasan pada rancangan sistem pakar diagnosa hama dan penyakit pada bunga krisan maka dapat disimpulkan bahwa Sistem dapat menndiagnosa hama dan penyakit pada bunga krisan melalui gejala-gejala yang dia alami dan diinputkan oleh para petani. Dan dalam melakukan diagnosa hama dan penyakit bunga krisan sistem akan memberikan pertanyaan gejala-gejala yang terdapat yang mungkin terjadi pada bunga krisan untuk diproses dengan runut maju (forward chaining) sehingga sistem akan memberikan informasi berupa hasil diagnosa.

Saran untuk pengembangan penelitian selanjutnya adalah dapat mengembangkan system yang dapat mengambil keputusan dengan metode factor kepastian (certainty factor) bila gejala-gejala yang di alami terdapat pada beberapa diagnose yang sama, yakni metode factor kepastian (certainty factor) akan memberikan nilai persentasi terhadap hasil diaganosa serta dapat mengembangkan aplikasi web ke apliasi android untuk mempermudah digunakan dimana saja 


\section{DAFTAR RUJUKAN}

Arhami, Muhammad. Konsep Dasar Sistem Pakar. Yogyakarta. Andi. 2005.

Harry, N.R. Usaha Tani Bunga Potong. Bogor. Pusat Perpustakaan Pertanian \& Komunikasi Penelitian. Badan Penelitian \& Pengembangan Pertanian. 1994.

Hasim dan Reza. Krisan. Jakarta. Swadaya . 1995.

Indrajani. Bedah Kilat 1 jam - Pengantar dan Sistem Basis Data. Elex Media Computindo. Jakarta. 2011.

Krismiaji. Sistem Informasi Akutansi. Unit Penerbit .Yogyakarta. 2010.

Kusrini. Aplikasi Sistem Pakar Menentukan Faktor Kepastian Pengguna dengan Metode Kuantifikasi Pertanyaan. Yogyakarta. Andi. 2008.

Kusrini. Sistem Pakar. Teori dan Aplikasi. Yogyakarta. Andi. 2006.

Kusumadewi, Sri. Intelligence (Teknik dan Aplikasinya). Yogyakarta. Graha Ilmu. 2003.

Lestary, DY. Cara pembuatan pupuk organic cair laporan hasil penelitian. Yogyakarta. Universitas Negeri Yogyakarta. 2012.

Rosnelly, Rika. Sistem Pakar Konsep dan Teori. Yogyakarta. Andi. 2003.

Rukmana, R. Dan A. E. Mulyana. Krisan (Seri bunga potong). yogyakarta. Kanisius. 1997.

Saputra, Agus. Trik dan Solusi Jitu Pemrograman PHP. Jakarta. PT.ElexMedia Komputindo. 2011.

Suyatno, Menjelajah Pembelajaran Inofatif. Sidoarjo. Masmedia Buana Pusaka. 2009. 